\title{
ICT instructors' sense of empowerment and viewpoint on the implementation of a national ICT program
}

\author{
Orit Avidov-Ungar ${ }^{1} \cdot$ Noga Magen Nagar ${ }^{2}$
}

Received: 15 December 2014/Revised: 23 February 2015/Accepted: 4 March 2015/

Published online: 19 March 2015

(C) Beijing Normal University 2015

\begin{abstract}
Within implementation of the National Information and Communication Technology (ICT) Program, ICT instructors facilitate schools with integrating ICT in teaching. Two types of ICT instructors take part in the implementation process: External district ICT instructors and internal school ICT instructors. This research has two goals: to examine how the ICT instructors perceive the encouraging and inhibiting factors of the change implementation, and to examine the factors predicting external district ICT instructors' sense of empowerment in comparison with internal school ICT instructors, thus examining the knowledge power PICTK (Program Information Communication Technology Knowledge) and TPACK knowledge (Technological Pedagogy and Content Knowledge) on the sense of empowerment within them. The methodology combines quantitative and qualitative research tools in a self-report questionnaire. The research findings clarify that the ICT instructors' sense of empowerment improves by enhancing their PICTK knowledge and TPACK knowledge. This sense of empowerment helps the instructor in creating viewpoints on the implementation process and the National Program's outcome. The research shows that the ICT instructors' viewpoints have unique significance to understanding the change elements that the National ICT Program creates in the schools. It is therefore recommended to continue with encouraging ICT instructors to expand their personal knowledge on the developing ICT program.
\end{abstract}

Orit Avidov-Ungar

Oritav65@gmail.com

Noga Magen Nagar

nogamagen@gmail.com

1 Achva Academic College, The Open University, Arugot, Israel

2 Ministry of Education, Gordon Academic College, Haifa, Israel 
Keywords PICTK knowledge - TPACK knowledge - Sense of empowerment • External district ICT instructors · Internal school ICT instructors · ICT implementation

\section{Introduction}

\section{Change in education systems}

The National Information and Communication Technology (ICT) Program in Israel, "adapting the education system in the 21 st Century", has been operating since 2010 and comprises hundreds of elementary and secondary schools, representing about $40 \%$ of the schools in Israel. The purpose of the program is to implement innovative pedagogy while employing 21 st century skills, with the help of information and communication technologies. The ICT program is holistic and encompasses five activities that complement each other:

(a) Adapting a curriculum for teaching-learning-assessment in the information era

(b) The pedagogical development of the teaching-learning-assessment processes integrated with a digital platform

(c) Professional development of teachers

(d) Establishment of ICT infrastructure and maintenance logistics

(e) Monitoring and evaluation of the program components.

Each school required learning-directed products in an online environment, innovative teaching methods, and a proactive ICT implementation team (consisting of both an internal school instructor and an external district instructor).

Models describing effective implementation of processes of change indicate that the first critical stage is the stage in which those involved in the implementation understand the need for this change (Cook et al. 2007; Shaw 2005), a sense of urgency is thus created among them, regarding the change as essential for improving and advancing the organizational system (Hargreaves and Goodson 2006). Yet even after understanding the need for the change, differences may exist between various interested parties in their perception of the goals of the change, in their personal and organizational interests, and in their attitudes toward the desired nature of the change (Fullan 2006; Fullan et al. 2004; Klein and Sorra 1996). In this context, ICT instructors are a major and critical element to the success of the change. The National ICT Program intends to create change by converting the school into a teleprocessing organization, which optimally implements ICT (Ministry of Education 2013a). The program was constructed based on a comprehensive approach found on a logical intervention model of inputs, outputs, and products, which creates a framework for planning, implementation, and evaluation. A close connection between inputs, outputs, and products demonstrates the logical basis of the intervention program's rationale (Sundra et al. 2003). Inputs of the ICT program include the resources given to the schools, which are mainly instruction, equipment, and routine maintenance. 
Each school's nature of instruction and contents is different and evaluated according to the school's perceived progress in the ICT program (Ministry of Education 2013a).

During the preparation stage for implementing the ICT program, designated ICT instructors were appointed from the teaching staff as well as ministry officers, whose role is to lead and assist the schools with the implementation of ICT according to the key performance indicators of the program. The ICT instructors' work is carried out at two levels: (1) Internal ICT instructor: At the school level, where the school's ICT coordinator, a member of the teaching staff, also serves as an ICT instructor who assists the school with introducing the technological change and guides the teachers toward successful implementation of the program's outputs; (2) External ICT instructor: At the district level, where a district ICT instructor, previously a teacher and now working for the Ministry of Education, is responsible for approximately five schools. The main role of this instructor is to guide each school's principal and internal ICT coordinator to realize all the outputs of the National ICT Program (Ministry of Education 2013b). The instructor's work is perceived as a consistent and continuous intervention process that assists the teacher in his or her professional development, with improvement in the quality of teaching and in the learning achievements (Ministry of Education 2013c). Choosing the teacher for the instruction role is therefore carried out via the appropriate pedagogical considerations. A teacher chosen to instruct other teachers in ICT is one with a professional-pedagogical authority to instruct. The teacher is chosen based on his or her extensive experience in the field and Technology Pedagogy and Content Knowledge (Ministry of Education 2013b), also known as TPACK; this knowledge characterizes the teacher's ability to include technology in teaching in an educated manner (Koehler and Mishra 2008).

The training and professional development of the ICT instructors constructs personal knowledge that includes insights from four aspects of the ICT program in Israel: Context, inputs, process, and products. The knowledge framework is a more advanced logical intervention model, the Context, Input, Process, Product (CIPP) model, which refers to the processes of implementation and change undergone by the schools. The instructors learn the ICT program, but furthermore, learn how to evaluate its components with reference to the school for which they are responsible. The context aspect refers to the preliminary planning and definition of the program and its justification. The input aspect refers to the structure of the program and to the strategic planning, which includes timetables, manpower, resource utilization, etc. The process aspect refers to the program's implementation and the quality of the process. The product aspect refers to achievements in the context of the program goals and effects, in terms of effectiveness and sustainability (Stufflebeam 2007). In the present study, this knowledge is called Program Information Communication Technology Knowledge (PICTK).

Chai et al. (2013) suggests that the TPACK framework may be used to facilitate deeper change in education, particularly in development and research of technological environments. Furthermore, the authors suggest crossing TPACK with other theoretical frameworks relating to the study of technology integration. The current study does just that, and crosses TPACK with the contextual knowledge PICTK. 


\section{Empowerment of appointment holders}

Empowerment means increasing the ability of the other to act (Conger and Kanungo 1988; Maeroff 1988; Muijs and Harris 2003; Short and Rinehart 1992). There are those who claim that empowerment is an ideology and a worldview, a process and not a single event; a person who lacks empowerment therefore does not actualize his or her professional potential (Sandy 2010; White 1992). According to Blase and Blase (1997), there are no people who absolutely lack empowerment or have absolute empowerment. Empowerment is defined on a developmental spectrum, on which people can move between greater or lesser empowerment. Thus, empowerment is not an "absolute threshold", but rather a dimension that changes with different intensities at different points in time (Zimmerman 1990). During the empowerment process, the person's belief in his or her ability to make decisions and solve problems is apparent, and this is therefore a process of personal growth (Muijs and Harris 2003). Empowerment of appointment holders, such as the ICT instructor, is a deliberate process whose goal is to develop and enable members of the organization to actualize their personal potential and growth, a process that enables actualization of personal qualities, a sense of belonging and belief in self-efficacy and self-control (Datnow et al. 2002).

Empowerment in the education system is based on the belief that people have skills and ability, but need experience and opportunities in order to express them (Dembele and Schwille 2006; Hargreaves 2005). Appointment holders in education systems who are empowered, active, and confident in their power, will also act beyond their fields of responsibility, initiate, and contribute to the success of the school and the organizational environment in which they function and/or to their success as professionals (Blase and Blase 1997; Irwin 1996). Appointment holders who are empowered have a higher sense of responsibility pertaining to their role and to the tasks they must perform, as well as the goals they should achieve (AvidovUngar et al. 2014). They are involved in choosing and developing curricula that best meet the needs of the system (White 1992), and in their work they also influence students' achievements (Pollak 2009; Reeves 2009).

Short \& Rinehart (1992) list six measures comprising a teacher's sense of empowerment: Decision-making, professional growth, status, self-efficacy, autonomy, and impact. Maeroff (1988) claims that the professional status of teachers and appointment holders in education systems can be improved by raising their selfimage, adding pedagogical and academic knowledge to their existing knowledge, and creating possibilities for work at an equal level with the principal and with other teachers (Cribner et al. 2001). Efficacy develops when these appointment holders acquire self-knowledge and believe that they have the necessary skills for the desired outcomes. Thus, a sense of self-efficacy empowers the appointment holder in his or her doing and performance (Bandura 1989). The empowerment process is one of the main factors which generates the process of change in education and enables its progress (Sandy 2010). Empowerment of appointment holders who are leaders and spearhead change is therefore an important resource, which assists the educational organization in coping with a changing reality (Avidov-Ungar and Shmir-Inbal 2013; Kaniuka 2012). 


\section{Research goals}

The research has two goals:

1. To examine how ICT instructors perceive the encouraging and inhibiting factors of the implementation of a National ICT Program, and review what is considered by them a success of the change.

2. To examine the effect of PICTK knowledge and TPACK knowledge on ICT instructors' sense of empowerment for facilitating the implementation of ICT in the schools.

The first research goal will be examined using qualitative research methods, and the second research goal will be examined using quantitative research methods.

Figure 1 presents the research model of the second research goal.

The Research hypotheses for the second research goal are as follows:

1. External ICT instructors and internal ICT instructors will perceive PICTK knowledge as influencing their sense of empowerment.

2. External ICT instructors and internal ICT instructors will perceive PICTK knowledge as influencing their TPACK knowledge during their instruction.

3. External ICT instructors and internal ICT instructors will perceive their instructive TPACK knowledge as influencing their sense of empowerment.

\section{Method}

\section{Participants}

The participants included 121 ICT instructors; therefore, this study should be considered as a pilot study (see Hair et al. 2010). The instructors were appointed in 2012-2013 by the Ministry of Education in order to promote teaching in an ICT environment in schools that participated in the National ICT Program. Of these, 77 $(64 \%)$ are external district ICT instructors and $44(36 \%)$ are internal school ICT

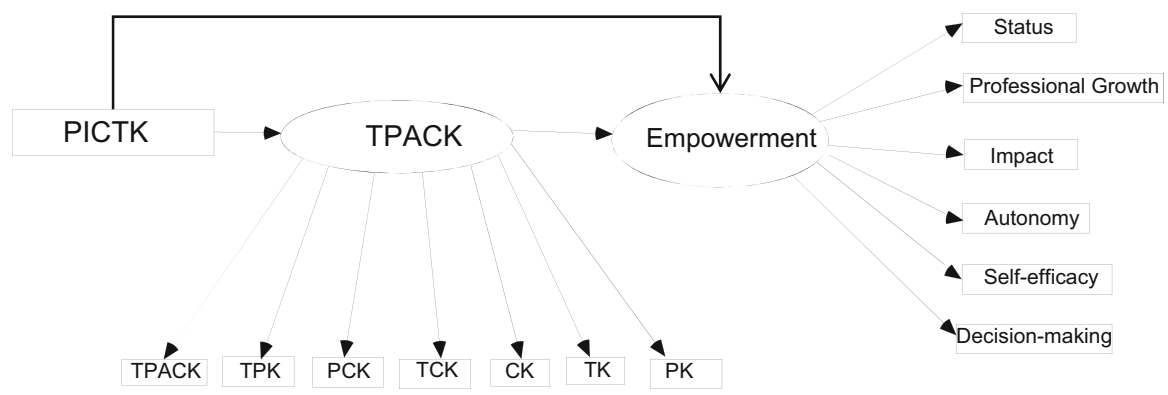

Fig. 1 The proposed research model 
Table 1 Distribution of the external district ICT instructors' and internal school ICT instructors' years of teaching experience $(\%)$

\begin{tabular}{llllr}
\hline Group & \multicolumn{4}{l}{ Teaching experience } \\
\cline { 2 - 5 } & 1-3 years & $4-5$ years & 6-10 years & 11 or more years \\
\hline External district ICT instructors & 63.6 & 10.4 & 6.5 & 18.2 \\
Internal school ICT instructors & 81.8 & 4.5 & 2.3 & 9.1 \\
\hline
\end{tabular}

instructors. About half (47.9\%) of the instructors have a teaching experience of 17 or more years and about half $(52.1 \%)$ have $4-16$ years of service. The majority $(64.5 \%)$ has an MA degree, about a third (28.9\%) has a BA degree, and a few $(2.5 \%)$ have a Ph.D. Table 1 presents the distribution of the district ICT instructors' and internal school ICT instructors' years of teaching experience.

\section{The research tool}

The research tool is a self-report questionnaire. The questionnaire included one qualitative section in which there were open questions, as well as a second quantitative section comprising a viewpoint questionnaire. The description is as follows:

\section{The qualitative section}

In this section, we asked the participants 3 open questions:

1. What do you think helps implement the National ICT Program in the schools?

2. What do you think delays the implementation of the ICT program in the school?

3. What do you think would be considered as effective implementation of the ICT program in the school?

This part appeared in the beginning of the questionnaire in order to prevent a deviation by the quantitative section. A whole page was left for the participants to write their answers to the three open questions that were asked.

\section{The quantitative section}

The research hypotheses were tested using four questionnaires that were administered to the ICT instructors:

1. Empowerment questionnaire The sense of empowerment was measured using a questionnaire developed by Short and Rinehart (1992). The questionnaire tests the perception of the responders regarding the extent of their empowerment on issues related to their work as instructors. The questionnaire contains 29 items that were adapted to the work of the instructors. It is constructed on a 5-level Likert scale. The sense of empowerment was measured according to six measures: 1. Decisionmaking, the choice of what and how to instruct; 2 . Role status, the sense of esteem 
and respect, and functioning in a professional environment; 3. Role autonomy, control over the agenda and schedule; 4 . Sense of self-efficacy, belief in the self and the feeling that "I am leading others to growth, change and empowerment"; 5. Professional growth, knowledge, learning, involvement in the curricula, and being an active participant in processes of team development; 6 . Impact, the opportunity to collaborate in a team, to teach others, to contribute knowledge and influence teachers and principals. A high internal consistency was found for the six subscales. Table 2 presents the measures of the questionnaire, the means, standard deviations, and reliabilities.

2. PICTK knowledge (Program Information Communication Technology Knowledge) questionnaire This questionnaire was intended to test the knowledge of the ICT instructors in the National ICT Program. The questionnaire was constructed for the present study and included 10 statements on a 5-level Likert scale. The reliability of the questionnaire was $\alpha=0.86$. An example of an item is "The ICT program is based on an ICT model of innovative technology".

3. Instructive TPACK knowledge (Technology Pedagogy and Content Knowledge) questionnaire A TPACK questionnaire that was developed by Koehler and Mishra (2008) was adapted to the current study in order to test the instructive TPACK knowledge of the ICT instructors. The questionnaire was adapted to the field of instruction. We asked senior ICT instructors to go over the questionnaire and test the compatibility of the items to the field of instruction. The questionnaire was given to eight judges and their comments were taken into account when constructing the final version of the questionnaire. The questionnaire tests the extent to which technology is used in instruction on a 5-level Likert scale. The questionnaire contains seven measures: Pedagogical knowledge, technological knowledge, content knowledge in the field of knowledge, pedagogical content knowledge in the field of knowledge, technological content knowledge in the field of knowledge, technological

Table 2 Measures of the empowerment questionnaire-means, standard deviations, and reliabilities $(N=121)$

\begin{tabular}{|c|c|c|c|c|c|}
\hline $\begin{array}{l}\text { Questionnaire } \\
\text { measures }\end{array}$ & $\begin{array}{l}\text { No. of } \\
\text { items }\end{array}$ & Example & M & $\mathrm{SD}$ & $\begin{array}{l}\text { Cronbach's } \\
\text { Alpha }\end{array}$ \\
\hline Decision-making & 6 & $\begin{array}{l}\text { I am involved in decisions that are related to } \\
\text { the instruction budget in the district/schools }\end{array}$ & 3.78 & 0.55 & 0.64 \\
\hline Status & 6 & My colleagues treat me with respect & 4.44 & 0.48 & 0.72 \\
\hline Autonomy & 3 & I am able to plan my own schedule & 4.32 & 0.66 & 0.74 \\
\hline Self-efficacy & 5 & I believe that I am good at what I do & 4.59 & 0.45 & 0.75 \\
\hline $\begin{array}{l}\text { Professional } \\
\text { Growth }\end{array}$ & 4 & $\begin{array}{l}\text { Instruction gives me an opportunity to } \\
\text { continue to study and become more } \\
\text { professional }\end{array}$ & 4.24 & 0.75 & 0.77 \\
\hline Impact & 5 & Colleagues at work tend to listen to my advice & 4.29 & 0.62 & 0.80 \\
\hline $\begin{array}{l}\text { All empowerment } \\
\text { questionnaire } \\
\text { items }\end{array}$ & 29 & & 4.26 & 0.47 & 0.93 \\
\hline
\end{tabular}


pedagogical knowledge, and technological pedagogical content knowledge. Table 3 presents the measures of the questionnaire and their means, standard deviations, and reliabilities.

4. Demographic questionnaire The instructors answered a demographic questionnaire, such as gender, age, role in the education system, academic education, years of teaching experience, and instruction experience.

\section{The research procedure}

At the beginning of the 2013 school year, the ICT instructors were asked to answer an online self-report questionnaire intended for the present study. Anonymity and confidentiality were ensured by not including identifying details in the questionnaire.

\section{Results}

The research findings are presented according to the two research tools used: the qualitative section and the quantitative section. After presenting the findings of the two methodologies, they will be integrated. Table 4 presents a comparison between the external ICT instructors and internal ICT instructors.

Table 3 Measures of the instructive TPACK knowledge-means, standard deviations, and reliabilities $(N=121)$

\begin{tabular}{|c|c|c|c|c|c|}
\hline $\begin{array}{l}\text { Questionnaire } \\
\text { measures }\end{array}$ & $\begin{array}{l}\text { No. } \\
\text { of } \\
\text { items }\end{array}$ & Example & M & SD & $\begin{array}{l}\text { Cronbach's } \\
\text { Alpha }\end{array}$ \\
\hline $\begin{array}{l}\text { Pedagogical } \\
\text { knowledge (PK) }\end{array}$ & 3 & $\begin{array}{l}\text { I am able to use a variety of teaching } \\
\text { styles when I instruct }\end{array}$ & 4.51 & 0.49 & 0.69 \\
\hline $\begin{array}{l}\text { Technological } \\
\text { knowledge (TK) }\end{array}$ & 4 & $\begin{array}{l}\text { I am able to solve technical problems that } \\
\text { are related to hardware }\end{array}$ & 3.94 & 0.68 & 0.82 \\
\hline $\begin{array}{l}\text { Content Knowledge } \\
\text { (CK) }\end{array}$ & 3 & $\begin{array}{l}\text { I can decide for myself the scope of the } \\
\text { learned content in the fields of my } \\
\text { instruction }\end{array}$ & 4.34 & 0.52 & 0.65 \\
\hline $\begin{array}{l}\text { Pedagogical content } \\
\text { knowledge (PCK) }\end{array}$ & 4 & $\begin{array}{l}\text { I am able to teach the teachers I instruct in } \\
\text { an online environment }\end{array}$ & 4.63 & 0.47 & 0.82 \\
\hline $\begin{array}{l}\text { Technological content } \\
\text { knowledge (TCK) }\end{array}$ & 3 & $\begin{array}{l}\text { I am able to create an online environment } \\
\text { that enables the teachers I instruct to } \\
\text { construct new knowledge and skills }\end{array}$ & 4.42 & 0.56 & 0.79 \\
\hline $\begin{array}{l}\text { Technological } \\
\text { pedagogical content } \\
\text { knowledge (TPK) }\end{array}$ & 4 & $\begin{array}{l}\text { I am able to conduct an online activity } \\
\text { among the teachers I instruct }\end{array}$ & 4.36 & 0.41 & 0.91 \\
\hline $\begin{array}{l}\text { Technological } \\
\text { pedagogical content } \\
\text { knowledge (TPACK) }\end{array}$ & 4 & $\begin{array}{l}\text { I am able to use technology in order to } \\
\text { successfully represent content that I } \\
\text { instruct }\end{array}$ & 4.18 & 0.61 & 0.74 \\
\hline $\begin{array}{l}\text { All instructive TPACK } \\
\text { knowledge } \\
\text { questionnaire items }\end{array}$ & 25 & & 4.33 & 0.42 & 0.92 \\
\hline
\end{tabular}


Table 4 A comparison between external ICT instructors and internal ICT instructors: what encourages and what delays implementation of ICT in teaching and what is considered as effective implementation

\begin{tabular}{|c|c|c|c|c|}
\hline & & $\begin{array}{l}\text { External } \\
\text { district } \\
\text { ICT } \\
\text { instructors } \\
(\%)\end{array}$ & $\begin{array}{l}\text { Internal } \\
\text { school } \\
\text { ICT } \\
\text { instructors } \\
(\%)\end{array}$ & Mean \\
\hline \multirow{4}{*}{$\begin{array}{l}\text { Implementation } \\
\text { encouraging } \\
\text { factors }\end{array}$} & Overall guidance of the implementation process & 56 & 52 & 55 \\
\hline & $\begin{array}{l}\text { Training and technological-pedagogical } \\
\text { guidance }\end{array}$ & 55 & 57 & 55 \\
\hline & Technological infrastructures & 40 & 30 & 36 \\
\hline & Financial reward & 10 & 7 & 9 \\
\hline \multirow{5}{*}{$\begin{array}{l}\text { Implementation } \\
\text { inhibiting } \\
\text { factors }\end{array}$} & Insufficiencies in overall guidance & 57 & 66 & 60 \\
\hline & Lack of sufficient technological infrastructures & 56 & 50 & 54 \\
\hline & $\begin{array}{l}\text { Quality/frequency of training and pedagogical- } \\
\text { technological guidance }\end{array}$ & 16 & 20 & 18 \\
\hline & Lack of financial reward & 1 & 2 & 2 \\
\hline & Teaching staff & 16 & 20 & 17 \\
\hline \multirow{4}{*}{$\begin{array}{l}\text { What is effective } \\
\text { implementation? }\end{array}$} & Basic ICT implementation & 81 & 82 & 81 \\
\hline & School progress in the ICT program & 34 & 50 & 40 \\
\hline & Personal growth of students & 29 & 30 & 29 \\
\hline & Personal growth of teachers & 18 & 18 & 18 \\
\hline
\end{tabular}

\section{Differences between external ICT instructors and internal ICT instructors in relation to the implementation of an ICT program}

The external district ICT instructors and internal school ICT instructors were asked about factors that encourage effective implementation of the ICT program in the schools, factors that delay implementation, and what would be considered as effective implementation. A summary of the findings from the qualitative analysis of the ICT instructors' answers is as follows:

\section{Encouraging factors of implementation}

From the instructors' answers, four central factors, to which the instructors referred to as encouraging effective implementation, were found. These factors are presented according to the frequency of the factors' descriptions:

(1) Overall guidance of the implementation process $55 \%$ of the instructors referred to the main factor of ICT implementation as the ability of the school administration and higher level decision-makers to lead the ICT program in the school in an effective way. Various statements were included under this factor, but the common denominator was the opinion that the ICT process cannot only exist as a specific project, but rather depends on management 
initiative and encouragement, i.e., running the project correctly and leading it in a way befitting the school's vision and characteristics. For example, the ICT instructors stated the importance of full cooperation of the school principal, ICT coordinator, and group leader as well as highly prioritizing the ICT program on the school's list of priorities.

(2) Training and technological-pedagogical guidance $55 \%$ of the instructors stated the importance of professional training processes and guiding the teaching staff on a technological-pedagogical level as a significant factor that encourages effective implementation processes of ICT in the school. For example, the instructors stated the importance of the continued support of the district and the importance of professional education programs in the implementation process.

(3) Technological infrastructures $36 \%$ of the instructors stated the importance of a suitable technological infrastructure as a main encouraging factor of implementation processes in the schools. The ICT instructors stated the importance of properly maintained and functioning equipment and available technical support.

(4) Financial reward $9 \%$ of the instructors referred to financial reward for the teachers as an important encouraging factor of implementation processes in the school. It is important to note that instructors referring to the financial reward mostly referred to other factors, as described above, so that it seems a financial reward may be of contribution but cannot be the only factor encouraging effective implementation.

\section{Inhibiting factors of implementation}

In an analysis of the instructors' statements on factors inhibiting effective implementation, a "mirror effect" was found, according to which most of the factors stated by the instructors as encouraging implementation were also perceived as inhibiting the ICT implementation in the school when these factors were absent or their efficiency was not satisfactory. Five main factors delaying ICT implementation in the school were named, but their frequency and intensity appeared in a different order, while an additional factor was stated as inhibiting implementation.

(1) Overall guidance $60 \%$ of the instructors referred to the shortcomings of overall guidance as an inhibiting factor; the instructors stated there is no clear vision as to what would be considered as a success. Each teacher does what he or she is able of and is good at.

(2) Lack of sufficient technological infrastructures $54 \%$ of the instructors made many statements concerning the technologically insufficient infrastructure in the schools.

(3) Quality and/or frequency of instruction and pedagogical-technological guidance $22 \%$ of the instructors referred to the instruction and guidance processes formed to assist with integrating ICT when teaching in the school. 
Participants stated that the designed training program teaches ICT tools but does not include developing pedagogical ICT-integrating teaching skills.

(4) Lack of financial reward $2 \%$ of the instructors referred to the fact that there is no reward at all for integrating ICT in teaching.

(5) Furthermore, $17 \%$ of the instructors referred to the teaching staff itself as an inhibiting factor of effective implementation processes, due to a low level of cooperation or previous technological knowledge that is not sufficient for integrating innovative teaching technologies. It is interesting to note that although the teachers' lack of technological knowledge and/or low motivation is perceived as an inhibiting factor; high motivation and technological skills were not described as encouraging implementation factors by the ICT instructors.

\section{Success in effectively integrating ICT in teaching}

The ICT instructors were asked what would be considered by them to be an effective implementation of ICT in teaching. From the instructors' answers, one could see there is no uniformity concerning effective implementation, in that the instructors referred to many components, including promoting thought processes, learning ICT skills, encouraging communication among teachers and between teachers and students, and improving the quality of teaching and school atmosphere.

Of the many components given by the instructors, four "super-components" were recognized referring to what effective integration of ICT in teaching is. These categories are presented according to the frequency of the statements in the instructors' answers.

Basic ICT implementation $81 \%$ of the ICT instructors referred to a basic implementation of ICT in teaching as a success, meaning the implementation effectiveness is measured by the extent of ICT application, without reference to using ICT as a pedagogical tool. The instructors referred to measures of combining ICT in all classes, for example.

School progress in the ICT program $40 \%$ of the instructors stated that for them, effective implementation means the school's progress according to the ICT program goals, such as a sharing culture between teachers and pedagogical thinking that combines ICT.

Personal growth of the students $29 \%$ of the instructors referred to personal growth of students as an effective implementation measure of the ICT program, i.e., a student who is independent in his work develops 21 st century learning skills and increases educational achievements.

Teacher's personal growth $18 \%$ of the instructors referred to the personal growth of the teaching staff as a measure of effective implementation of ICT in the school (e.g., teachers with a sense of success).

In Table 4, we compared the answers of the external district ICT instructors with the internal school ICT instructors. The table includes the frequency in percentages 
of each of the previously mentioned categories while comparing the two ICT instructor groups.

Furthermore, one may see that in most categories, the frequency of statements between the external district ICT instructors in comparison with the internal school ICT instructors is similar. However, when examining the frequency percentages, one can see that the external district ICT instructors tended to refer more $(40 \%)$ to the importance of technological infrastructures as an encouraging factor of implementation in comparison with the internal school ICT instructors (30\%). Additionally, one may see that the internal school ICT instructors tended to refer more $(50 \%)$ to effective implementation as the school's progress according to the ICT program's goals, in comparison with the external district ICT instructors (34\%). From the viewpoints and comprehension of the ICT instructors, one may conclude that the technological infrastructure and understanding of change as an overall school system change are those perceived as measures for effective implementation of the change.

\section{Differences between external ICT instructors and internal ICT instructors in relation to sense of empowerment, and PICTK knowledge and TPACK knowledge of this sense}

Path analysis with structural equation modeling using the AMOS 7.0 software (Analysis of Moment Structures) (Arbuckle 2006) was performed in order to test the effect of PICTK knowledge on instructive TPACK knowledge and their effect on the instructor's sense of empowerment. This software enables testing variables and relations between them simultaneously, as well as improving the test by referencing the measurement and structural models. This analysis can therefore confirm or reject the theory on which the research is based.

The first step in structural equation modeling is evaluating the measurement model, which is performed by testing measures that indicate its fit to the model. The four measures $\chi^{2}$, RMSEA, NFI, and CFI are used to test the model that best fits reality (Bentler and Bonett 1980; Kline 2005). Table 5 presents the fit measures of the proposed research model.

The results in Table 5 indicate a good fit of the proposed research model to the research data. The corrected measurement model's loading coefficients $(\lambda)$ of the external district ICT instructors and of the internal school ICT instructors are presented in Figs. 2 and 3.

Table 5 Fit measures of the proposed research model

\begin{tabular}{lll}
\hline Fit measures & Recommended levels of fit & Value of the measure \\
\hline$\chi^{2}$ & n.s. at $p<0.05$ & $113.671, p<0.05$ \\
$\chi^{2} / \mathrm{df}$ & $<5$ & 1.29 \\
$\mathrm{CFI}$ & $>0.90$ & 0.97 \\
NFI & $>0.90$ & 0.90 \\
RMSEA & $<0.08$ & 0.05 \\
\hline
\end{tabular}




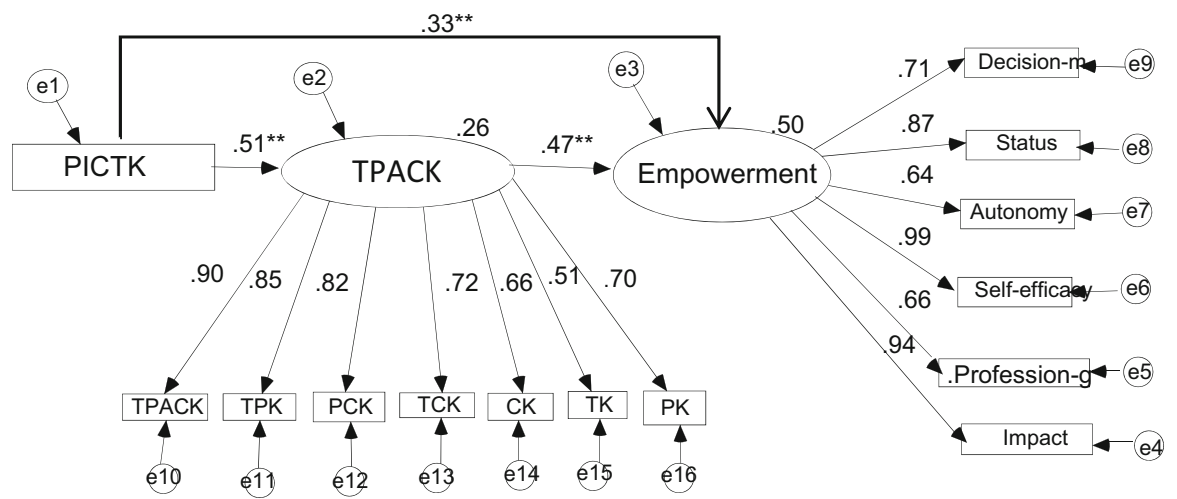

Fig. 2 Path analysis for external district ICT instructors

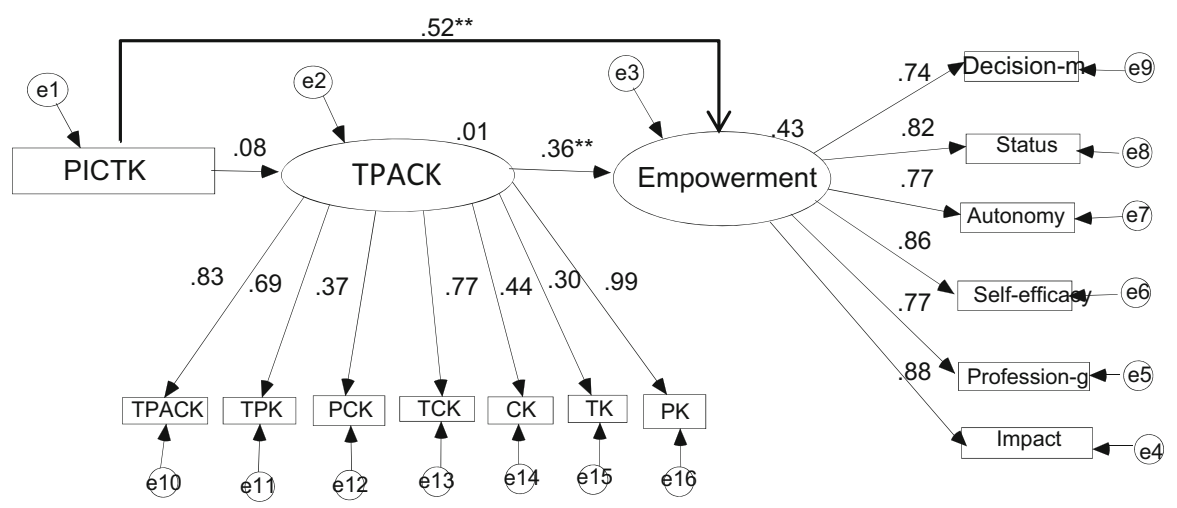

Fig. 3 Path analysis for internal school ICT instructors

The second step in structural equation modeling is evaluating the structural model that estimates the causal relations between two types of variables: Exogenous variables that are independent variables not affected by other variables in the model, and endogenous variables affected by other variables in the model. The exogenous variable in the present study is the observed variable PICTK. The endogenous variables are instructive TPACK and sense of empowerment. The variable instructive TPACK is a latent mediator variable that was measured by seven observed variables: PK, TK, CK, TCK, PCK, TPK, and TPACK. The variable sense of empowerment is a dependent and latent variable that was measured by six observed variables: Status, professional growth, impact, autonomy, self-efficacy, and decision-making. Figure 2 presents the path analysis of the external district ICT instructors, and Fig. 3 presents the path analysis of the internal school ICT instructors. Each figure presents the standardized effect coefficients $(\beta)$, the percent of explained variance $\left(R^{2}\right)$, and the standardized loading coefficients $(\lambda)$ of the observed variables. 
Convergent validity-estimation of the loading coefficients of the observed variables

Figures 2 and 3 indicate that most of the measures of the two latent variables (instructive TPACK knowledge and empowerment) are significant $(p<0.001)$ and reflect all the theoretical concepts in the model (except TK) among ICT instructors. It can be seen that the standardized loading coefficients $(\lambda)$ of the instructive TPACK knowledge range between 0.51 and 0.90 among external district ICT instructors, where the measure of TPACK knowledge was the most valid $(\lambda=0.99)$. Among the internal school ICT instructors, the standardized loading coefficients $(\lambda)$ of the instructive TPACK knowledge range between 0.30 and 0.99 , where the PK $(\lambda=0.99)$ was the most valid. The standardized loading coefficients $(\lambda)$ of the empowerment measures among the external district ICT instructors range between 0.64 and 0.99 , where self-efficacy $(\lambda=0.99)$ was obtained as the most valid, but not much more than the measure of impact $(\lambda=0.94)$. Among the internal school ICT instructors, the standardized loading coefficients $(\lambda)$ of the empowerment measures range from 0.74 to 0.88 , where the measure of impact $(\lambda=0.88)$ was the most valid.

The results of the quality of measurement model and estimation of the observed variables' loading coefficients indicate that all of the concepts were measured in a valid manner, and therefore strengthen the theoretical basis that guided the choice of the different measures for the two groups.

\section{Testing the structural model and confirmation of the research hypotheses}

Figures 2 and 3 demonstrate a similar scenario of a high level of explained variance of empowerment among the external district ICT instructors and the internal school ICT instructors, which is explained by PICTK knowledge and instructive TPACK knowledge (50 and $43 \%$, respectively). However, the PICTK knowledge explains about one third of the explained variance $(26 \%)$ of the instructive TPACK knowledge among the external district ICT instructors, whereas among the internal school ICT instructors, PICTK knowledge does not explain the instructive TPACK knowledge $(1 \%)$.

When testing the first research hypothesis, it can be seen that among the external district ICT instructors, PICTK knowledge has a significant moderate positive effect on the empowerment level $(\beta=0.33, p<0.001)$, and among the internal school ICT instructors this effect is even stronger $(\beta=0.52, p<0.001)$. Thus, the greater the PICTK knowledge of the ICT instructor, the greater is his or her sense of empowerment, so the hypothesis was confirmed.

When testing the second research hypothesis, it can be seen that among the external district ICT instructors, PICTK knowledge has a significant positive effect on instructive TPACK knowledge $(\beta=0.51, p<0.001)$. Thus, the greater the PICTK knowledge of the external district ICT instructor, the greater is his or her TPACK knowledge. However, PICTK knowledge has no effect on the TPACK knowledge among the internal school ICT instructors $(\beta=0.08 . p>0.05)$. Thus, the hypothesis was confirmed only among the external district ICT instructors. 
When testing the third research hypothesis, it can be seen that among the external district ICT instructors, instructive TPACK knowledge has a significant strong positive effect on the level of empowerment $(\beta=0.47, p<0.001)$. Among the internal school ICT instructors, this effect is moderate $(\beta=0.36, p<0.001)$. Thus, the greater the TPACK knowledge of the ICT instructor, the greater is his or her sense of empowerment; the hypothesis was confirmed.

\section{Discussion and conclusions}

The concept of empowerment includes a range of meanings that pertain to the cultivation of the individual and strengthening him or her and his or her function in the personal and organizational environment in which he or she operates (Hemric et al. 2010). Thus, empowerment is a process that can be motivated by the individual, while the organization can supply the climate and means for achieving better control of the individual over his or her environment (Pollak 2009; Reeves 2009). Empowered individuals have a high motivation for action and change, are driven by learning and innovation, and are characterized realizing goals they define for themselves (Johnson and Short 1988; Segedin 2011).

Due to the nature of the job, the ICT instructors are characterized by being active and willing to achieve the goals of their duty. It was therefore observed that their viewpoints concerning encouraging and inhibiting factors of effective implementation relate to the sense of empowerment among them. From the qualitative analysis, it is found that in order to implement effective ICT integration in teaching, the change and its desirable results must be clearly defined on the overall level, on the school level, on the teachers' level, and on the students' level. The research clarified that internal school ICT instructors tended to refer more to effective implementation as a school's progress in the ICT program compared to the external district ICT instructors. Furthermore, it was observed from the viewpoints and perceptions of the ICT instructors that the technological infrastructure and understanding of the change as an overall change of the school are perceived as measures for effective implementation of the change.

The findings regarding the quantitative research hypothesis indicate that ICT instructors perceive PICTK knowledge as affecting their sense of empowerment. PICTK knowledge has a significant moderate or higher positive effect on the sense of empowerment of both groups of ICT instructors. It is therefore recommended to continue encouraging the different ICT instructors to expand their personal knowledge on the evolving ICT program. The aim is to have the ICT instructor use PICTK knowledge to understand the processes of change taking place in the school, such that he or she will be able to formulate an instruction plan adapted to the needs and goals of the institution, out of a sense of strong internal empowerment. The products of empowerment are raising the status and strengthening the knowledge, abilities, and professional skills of the appointment holders (Avidov-Ungar et al. 2014; Avidov-Ungar and Shmir-Inbal 2013; Lecos et al. 2000). Knowledge on the ICT program thus becomes empowering knowledge for the appointment holder. 
The findings also indicate that the ICT instructors perceive PICTK knowledge as affecting their TPACK knowledge. PICTK knowledge has a significant positive effect on instructive TPACK knowledge only among external district ICT instructors, whereas it has no effect among internal school ICT instructors. The findings indicate that knowledge of the ICT program, i.e., PICTK knowledge, does not necessarily promote the TPACK knowledge of the internal school ICT instructors, but has critical significance for their sense of empowerment. It is possible that these ICT instructors regard their instructive role from a focus on the practice of teaching, and less for the promotion of a broad perception of the ICT program in the school context. On the other hand, it can be assumed that the external district ICT instructors base their instruction work, which includes TPACK knowledge, on the knowledge they acquired regarding the ICT program, i.e., PICTK knowledge, and are able to connect between the actions of the types of knowledge. This viewpoint may cause a stronger sense of empowerment than among the internal school ICT instructors.

Banathy (1992) claims that a comprehensive viewpoint is constructed based on the integration of related concepts, since it is then possible to organize them into a model. This study demonstrated this, by crossing the TPACK framework with PICTK, in order to further explore and facilitate change in technology integration in education. Empowered appointment holders in education have a higher sense of responsibility pertaining to their role and the goals they must achieve. It is reasonable to assume that the external district ICT instructors act out of a greater feeling of responsibility in a broader sense, enabling the connection between the information items on the PICTK programs and items of instructive TPACK knowledge; this enhances their sense of empowerment.

Furthermore, the findings indicate that both groups of ICT instructors perceive TPACK knowledge as affecting their sense of empowerment. Hence, they can plan the instruction content, instruct the teachers on teaching strategies in an ICT environment, etc. Empowered appointment holders in education systems, including ICT instructors, will also act beyond their fields of responsibility, will initiate, and will contribute to the success of the school, the organizational environment, and to their own success as professionals (Irwin 1996).

It can therefore be assumed that ICT instructors with instructive TPACK knowledge adapted to the teachers' and the schools' needs are teachers with a high level of TPACK knowledge, who have a broader viewpoint that enables them to use this knowledge when instructing teachers. Thus, they are seen as successful in their work on one hand and are meaningful to the environment on the other hand. These findings strengthen the claim of Avidov-Ungar et al. (2014) that a deep understanding of the demands of the role, accepting a broad role in an early stage of one's career, participating in a growth-promoting learning framework, and regarding the school as an organizational comprehensive framework are factors that promote a higher sense of empowerment among appointment holders in education systems. The research findings renew the meaning of TPACK knowledge of ICT instructors. It is therefore important to learn the essence of instructive TPACK knowledge in the professional development of ICT instructors. This includes broad aspects composed of pedagogy and content from the different fields of knowledge 
and technology, such as the efficacy to create an online environment in which the instructed person may construct new knowledge and skills. It is possible that this will enable better results in the implementation of the ICT program in the school.

The research findings express the three roles of the ICT instructor: the instructor as a technology leader, the instructor as a pedagogy leader, and the instructor as a leader of change (Comber and Lawson 1999; Lai and Pratt 2004). The perception of the instructor's role affects the understanding of the role, influences preferences, and the manner in which he or she performs the tasks derived from the demands of the role (Markham 1998; Moursund 1992).

In addition, the perception of the instructors regarding what encourages and inhibits effective implementation of ICT in teaching is also an influencing factor of their function within the change domain for which they are responsible.

It was further found that when a sense of empowerment exists, performance of the role is carried out with maximal efficiency (Dembele and Schwille 2006).

In conclusion, the present research findings further clarify the essence of both the external and internal ICT instructor role. The findings show that acquiring knowledge on the change plan is a necessary and critical initial stage for the professional role of the ICT instructor, since he or she aids his or her own role's empowerment on the one hand, while on the other he or she allows himself or herself to create viewpoints on the ICT program's implementation process and determine measures for its success.

Combining the components examined in the quantitative analysis (sense of empowerment, knowledge of the ICT program, and TPACK knowledge), with the components examined in the qualitative analysis, creates a full picture of the different aspects-behavioral, emotional and cognitive-involved in the change processes of combining ICT with teaching within a national program in schools.

The model created following the research findings and shown hereinafter demonstrates the importance of each of the influencing factors on the ICT instructor's function, to understanding his or her role in the implementation of change. One may learn that in order to succeed in fulfilling the role, it is important that the ICT instructor be aware of inhibiting and encouraging factors of change implementation, and would be able to precisely define the success measures in the change implementation. Moreover, as previously stated, the ICT instructor's sense of empowerment may improve the more PICTK knowledge and TPACK knowledge he or she has. One can also assume that the viewpoints reflecting behavioral and emotional orientations of change may also influence actions and feelings of empowerment in the guidance process of the school, as well as PICTK knowledge and TPACK knowledge. Therefore, the ICT instructors' viewpoints have unique significance in relation to understanding the depth of change the ICT program creates in the school. Identifying encouraging and inhibiting factors and choosing the plan's success measures are tested by the ICT instructor's knowledge. The suggested model is shown in Fig. 4.

In future research, it is recommended to expand the scope of participants and examine the differences between the tested groups of the present research and another group of implementing appointment holders, such as teachers and principals, and examine if there is a gap between those directly in charge of the 


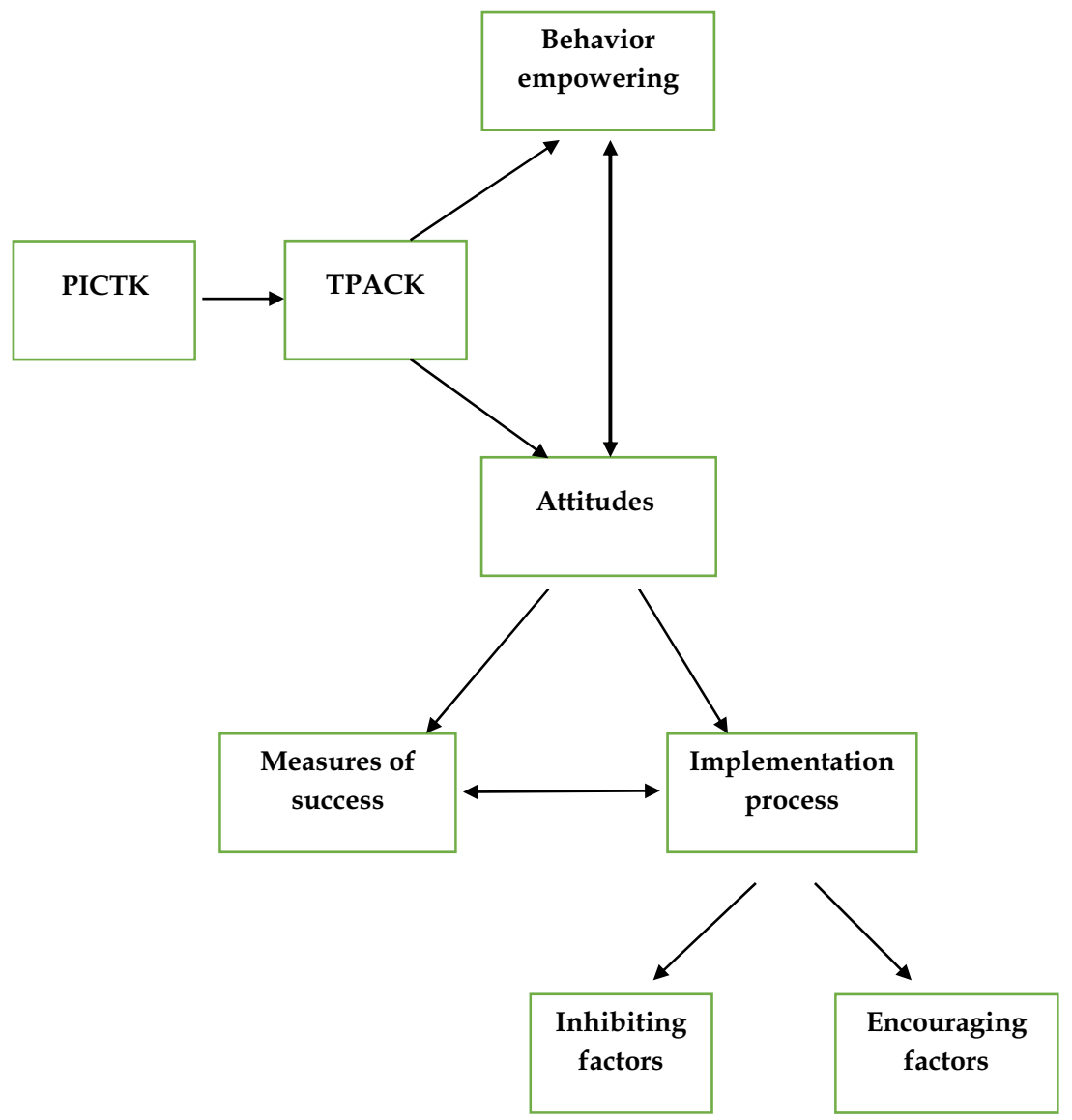

Fig. 4 ICT instructors' sense of empowerment and viewpoint on the implementation of a National ICT Program

implementation and the appointment holders at the school and district levels. Furthermore, it is recommended to examine additional factors, both personal and professional, which may influence instructional TPACK knowledge and the ICT instructors' sense of empowerment, among various appointment holders.

\section{References}

Arbuckle, J. L. (2006). AMOS 7.0 User's Guide. Chicago: SPSS.

Avidov-Ungar, O., Friedman, I., \& Olshtain, E. (2014). Empowerment amongst teachers holding leadership positions. Teachers and Teaching: Theory and Practice, 20(3), 1-17.

Avidov-Ungar, O., \& Shmir-Inbal, T. (2013). Empowerment patterns of leaders in ICT and school strengths following the implementation of national ICT reform. Journal of Information Technology Education: Innovations in Practice, 12, 141-158. 
Banathy, B. (1992). A systems view of education: Concepts and principles for effective action. Englewood Cliffs, NJ: Education Technology Publications.

Bandura, A. (1989). Human agency in social cognitive theory. American Psychologist, 44, 1175-1184.

Bentler, P. M., \& Bonett, D. G. (1980). Significance tests and goodness of fit in the analysis of covariance structures. Psychological Bulletin, 88, 588-606.

Blase, J., \& Blase, J. (1997). The micropolitical orientation of facilitative school principals and its effects on teachers' sense of empowerment. Journal of Educational Administration, 35(2), 138-164.

Chai, C. S., Koh, J. H., \& Tsai, C. C. (2013). A review of technological pedagogical content knowledge. Educational Technology \& Society, 16(2), 31-51.

Comber, C. A., \& Lawson, T. A. (1999). Superhighways technology: Personnel factors leading to successful integration of information and communications technology in schools and colleges. Technology, Pedagogy and Education, 8(1), 41-53.

Conger, J. A., \& Kanungo, R. N. (1988). The empowerment process: Integrating theory and practice. Academy of Management Review, 31(3), 471-482.

Cook, J., Holley, D., \& Andrew, D. (2007). A stakeholder approach to implementing e-learning in a university. British Journal of Educational Technology, 38(5), 784-794.

Cribner, J. P., Truell, A. D., Hager, D. R., \& Srichai, S. (2001). An exploratory study of career and technical education teacher empowerment: Implications for school leaders. Journal of Career and Technical Education, 18(1), 46-57.

Datnow, A., Hubbard, L., \& Mehan, H. (2002). Extending educational reform: From one school to many. London: Routledge Falmer.

Dembele, M., \& Schwille, J. (2006). Can the global trend toward accountability be reconciled with ideals of teacher empowerment? Theory and practice in Guinea. International Journal of Educational Research, 45(4-5), 302-314.

Fullan, M. (2006). The future of educational change: System thinkers in action. Journal of Educational Change, 7(3), 113-122.

Fullan, M., Bertani, A., \& Quinn, J. (2004). New lessons for district wide reform. Educational Leadership: Leading in Tough Times, 61(7), 42-46.

Hair, J. R., Black, W. C., Babin, B. J., \& Anderson, R. E. (2010). Multivariate data analysis (7th ed.). New York: Macmillan.

Hargreaves, A. (2005). Educational change takes ages: Life, career and generational factor in teacher emotional responses to educational change. Teaching and teacher Education, 21, 267-983.

Hargreaves, A., \& Goodson, I. (2006). Educational change over time? The sustainability and nonsustainability of three decades of secondary school change and continuity. Educational Administration Quarterly, 42(1), 3-41.

Hemric, M., Eury, A. D., \& Shellman, D. (2010). Correlations between perceived teacher empowerment and perceived sense of teacher self-efficacy. Journal of Scholarship and Practice, 7(1), 37-50.

Irwin, J. W. (1996). Empowering ourselves and transforming schools: Educators making a difference. Albany, NY: State University of New York Press.

Johnson, P., \& Short, P. (1988). Principal's leader power, teacher empowerment, teacher compliance and conflict. Educational Management \& Administration, 26(2), 147-159.

Kaniuka, T. S. (2012). Toward an understanding of how teachers change during school reform: Considerations for educational leadership and school improvement. Journal of Educational Change, 13(3), 327-346.

Klein, K. J., \& Sorra, J. S. (1996). The challenge of innovation implementation. The Academy of Management Review, 21(4), 1055-1080.

Kline, R. B. (Ed.). (2005). Principles and Practice of Structural Equation Modeling. New York: Guilford.

Koehler, M., \& Mishra, P. (2008). Introducing TPCK. In AACTE Committee on Innovation and Technology (Ed.), Handbook of Technological Pedagogical Content Knowledge (TPCK). New York: Routledge.

Lai, K. W., \& Pratt, K. (2004). ICT leadership in secondary schools: The role of the computer coordinator. British Journal of Educational Technology, 35(4), 461-475.

Lecos, M. A., Cassella, C., Evans, C., Leahy, C., Liess, E., \& Lucas, T. (2000). Empowering teacher leadership in professional development schools. Teaching and Change, 8(1), 98-113.

Maeroff, G. I. (1988). The empowerment of teachers: Overcoming the crisis of confidence. New York, NY: Teachers College Press.

Markham, S. K. (1998). A longitudinal examination of how champions influence others to support their projects. Journal of Product Innovation Management, 15, 490-504. 
Ministry of Education (2013a). Adaptation of the education system to the 21st Century. Science and Technology Administration, Ministry of Education. http://cms.education.gov.il/educationcms/units/ madatech/ictineducation. Accessed 1 September 2013 [Hebrew].

Ministry of Education (2013b). Periodical 3 for elementary schools in the second and third years, AprilJune 2013. Adaptation of the education system to the $21^{\text {st }}$ Century. Science and Technology Administration, Ministry of Education. http://cms.education.gov.il/EducationCMS/Units/ MadaTech/ICTInEducation/MismachimVenehalim/Hozerey_Agaf/Hozer_Agaf.htm. Accessed 1 September 2013 [Hebrew].

Ministry of Education (2013c). Periodical of the General Administration 2014/2 (b) 8.3-4. Education Workers in Instruction Roles. http://cms.education.gov.il/EducationCMS/applications/mankal/arc/ sd2bk8_3_4.htm. Accessed 1 September 2013 [Hebrew].

Moursund, D. (1992). The technology coordinator international society for technology in education. Oreon: Eugene.

Muijs, D., \& Harris, A. (2003). Teacher leadership-improvement through empowerment? An overview of the literature. Educational Management \& Administration, 31(4), 437-448.

Pollak, C. J. (2009). Teacher empowerment and collaboration enhances student engagement. San Rafael, CA: Master of Science in Education, School of Education, Dominican University of California.

Reeves, D. B. (2009). Model teachers. Association for Supervision and Curriculum Development, 66(5), $85-86$.

Sandy, L. D. (2010). Social capital, empowerment and educational change: A scenario of permeation of one-to-one technology in school. Journal of Computer Assisted learning, 26(4), 284-295.

Segedin, L. (2011). The role of teacher empowerment and teacher accountability in school-university partnerships and action research. Brock Education, 20(2), 43-64.

Shaw, G. (2005). Collaboration in aid-ICT In teacher education: But what about sustainability? In S. Garg, S. Panda, C. R. K. Murthy, \& S. Mishra (Eds.), Open and distance education in global environment: opportunities for collaboration. New Delhi: Viva Books Inc.

Short, P. M., \& Rinehart, J. S. (1992). School participant empowerment scale: Assessment of the level of participant empowerment in the school. Educational and Psychological Measurement, 54(2), 951-960.

Stufflebeam, D. L (2007). Cipp Evaluation Model Checklist. http://www.wmich.edu/evalctr/archive checklists/cippchecklist_mar07.pdf. Accessed 21 February 2012.

Sundra, D. L., Scherer, J., \& Anderson, L. A. (2003). A Guide to Logic Model Development for CDC's Prevention Research Centre. Atlanta, GA: Prevention Research Centers Program Office, Centers for Disease Control http://www.ojp.usdoj.gov/BJA/evaluation/guide/documents/cdc-logic-modeldevelopment.pdf. Accessed 21 February 2012.

White, P. A. (1992). Teacher empowerment under "ideal" school-site autonomy. Educational Evaluation and Policy Analysis, 14(1), 69-82.

Zimmerman, M. A. (1990). Taking aim on empowerment research: On the distinction between individual and psychological conceptions. American Journal of Community Psychology, 18, 169-177.

Orit Avidov-Ungar is the Head of Research Authority and senior lecturer at the School of Education Systems Management at Achva Academic College. She is also a member of the faculty of the Open University of Israel. She heads the team specializing in professional development at the Mofet Institute and is academic advisor to the Ministry of Education in Israel on management of the implementation of innovative technology systems and the professional development of teachers. Her research studies deal with the implementation of innovative technologies in education systems, the empowerment and professional development of teachers, and leading organizational change in education systems.

Noga Magen-Nagar is a Senior Lecturer and Director of MA Program of Teaching and Learning: Educators' Mentorship Training, Gordon Academic College of Education. She is a researcher and academic consultant in the national ICT program entitled "Adapting the education system to the 21st century", in the Department of Science and Technology, Ministry of Education. She is also a postdoctoral fellow at the Department of Education, Ben- Gurion University. Her areas of research include integrating ICT in education, the quality of teaching, teachers' attributes, and autonomy in education. 